\title{
Denetimli Serbestlik Polikliniğine Başvuran Madde Kullanım Bozukluğu Tanılı Bireylerde Intihar Davranışı
}

\section{Suicidal Behavior in Individuals with Substance Use Disorder Who Apply to the Probation Outpatient Clinic}

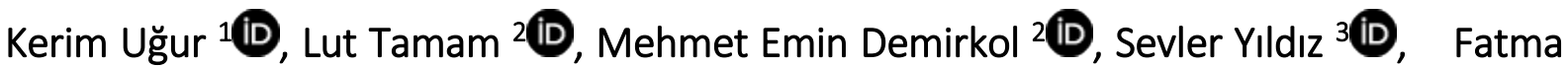 \\ Kartal 4(D), Aslı Kazğan 5(D), Hatice Polat 4(iD)
}

1. Malatya Turgut Özal Üniversitesi Tıp Fakültesi, Ruh Sağlı̆ı ve Hastalıkları Anabilim Dalı, Malatya.

2. Cukurova Üniversitesi Tıp Fakültesi Ruh Sağlığı ve Hastalıkları Anabilim Dalı, Adana.

3. Erzincan Binali Yıldıım Üniversitesi Tıp Fakültesi, Ruh Sağlığı ve Hastalıkları Anabilim Dalı, Erzincan

4. Malatya Eğitim ve Araştırma Hastanesi Ruh Sağlığı ve Hastalıkları Birimi, Malatya

5. Şanlıurfa Siverek Devlet Hastanesi, Ruh Sağıı̆ı ve Hastalıkları Birimi, Şanlıurfa

\section{Abstract}

Objective: The aim of this study was to investigate the correlation between psychological pain, childhood mental trauma, alexithymia, impulsivity and psychological resilience and suicide attempts in individuals with substance use disorder (SUD) who applied to the Probation Outpatient Clinic.

Method: The study was conducted with 120 individuals who applied to the probation outpatient clinic and healthy controls. Socio-Demographic Data Form, Childhood Psychological Trauma Scale (CTQ-28), Toronto Alexithymia Scale (TAS), Psychological Pain Scale (PP), Barratt Impulsiveness Scale (BIS), Psychological Resilience Scale (PRS) were applied to all participants.

Results: PP, TAS, BIS, CTQ-28 scale scores of patients with suicide attempt history were higher. In the forward stepwise model designed to predict the risk of suicide attempt, PRS, TAS-A, PRS-social competence and BIS-total scores contributed significantly to the model. It was determined that the four significant variables explained $65,6 \%$ of the variance in suicide risk.

Conclusion: High psychological pain, alexithymia, impulsivity and childhood trauma and low psychological resilience in individuals with substance use disorder could be a predictor of suicide risk.

Keywords: Probation, substance use disorder, childhood traumas, alexithymia

Öz

Amaç: Bu çalışmada Denetimli Serbestlik (DS) Polikliniğine başvuran Madde Kullanım Bozukluğu (MKB) tanılı bireylerde psikolojik acı, çocukluk çağı ruhsal travmaları, aleksitimi, dürtüsellik ve psikolojik dayanıkılığın intihar girişimi ile ilişkisinin incelenmesi amaçlanmıştır.

Yöntem: Çalışma DS Polikliniğine başvuran 120 kişi ve sağıklı kontrol ile yapılmıştır. Tüm katılımcılara; SosyoDemografik Veri Formu, Çocukluk Çağı Ruhsal Travma Ölçeği (CTQ-28), Toronto Aleksitimi Ölçeği (TAÖ), Psikolojik Acı Ölçeği (PAÖ), Barratt Dürtüsellik ölçeği (BDÖ), Psikolojik Dayanıklılık ölçeği (PDÖ) uygulanmıştır.

Bulgular: İntihar girişimi olan hastaların PAÖ, TAÖ, BDÖ, CTQ-28 ölçek puanlarının daha yüksek olduğu tespit edilmiştir. İntihar girişimi riskini tahmin etmek için kurulan modelde (forward stepwise) PAÖ, TAÖ-A, PDÖ-sosyal yeterlilik ve BDÖ-toplam değişkenlerinin modele anlamlı katkı yaptığı bulunmuştur. Anlamlı olan dört değişkenin intihar riskindeki değişimin \% 65,6'sını açıkladığı tespit edilmiştir.

Sonuç: MKB'lerde psikolojik acı, aleksitimi, dürtüsellik ve çocukluk çağı travmalarının yüksek, psikolojik dayanıkılığın daha düşük olmasının intihar riskini değerlendirmede öngörürücü etkenlerdir.

Anahtar kelimeler: Denetimli serbestlik, madde kullanım bozukluğu, çocukluk çağı travmaları, aleksitimi 


\section{Giriş}

Dünya Sağlık Örgütü her yıl 800000 kişinin intihar nedeniyle hayatını kaybettiğini bildirmiştir (1). İntihar girişimi 'ölüme neden olmak amacıyla kendine kasıtlı zarar verme' olarak tanımlanır ve psikososyal, nörobiyolojik, psikopatolojik faktörleri içeren çok yönlü bir durumdur (2). Gün geçtikçe yaygınlığı artan Madde Kullanım Bozukluğu (MKB)'da artan intihar riski ile ilişkilendirilmiştir (3). Madde ve Alkol Kullanım Bozukluğu ile intihar birlikteliğinin \%15 gibi yüksek oranlarda olduğu bildirilmiştir (4). MKB'nin özellikle intihar girişimi sonucunda ölen ergen ve gençlerde sık olduğu ve intihar riskini 2-4 kez arttırdığı bildirilmiştir (5). Denetimli serbestlik (DS), kişinin işlediği bir suçtan dolayı tutuklanması ya da mahkemece hakkında mahkûmiyet kararı verilmesi sonrası cezaevinde cezasının uygulanması yerine, cezasının toplum içerisinde gözetim ve denetim altında uygulanması anlamına gelmektedir (6). Uyuşturucu veya uyarıcı madde kullanan kişiler hakkında, tedavi ve DS tedbirine başvurulabilmektedir (7). Toplumda MKB tanılı bireylerin sayısının azaltılmasında ve bunların tedavi edilmesinde DS uygulamasının kişiye katkı sağladığı bildirilmiştir (8).

İntihar davranışı ile yakından ilişkili bulunan psikolojik acl; kayıp yaşama, travmatik olaylara uğrama, düş kırıklı̆ı, kişinin beklentilerinin olumsuz sonuçlanması, temel gereksinmelerin karşılanmaması gibi durumlardan kaynaklanabilen zihinsel acı çekme sürecidir $(9,10)$. Psikolojik acının intihar davranışı için depresyondan bağımsız bir risk etkeni olduğu bildirilmiştir (11). İntihar notlarındaki yaygın bir ifade, "acıya (zihinsel) artık dayanamıyorum" dur. Bu durumda kişilerin acıdan kaçmanın bir yolu olarak intiharı deneyebileceği bildirilmiştir (12). Çocukluktaki cinsel, fiziksel ve duygusal istismarı ve inmali kapsayan bir terim olan çocukluk çağı travmalarının MKB tanılı bireylerde intihar riskini arttıran bir risk faktörü olduğu gösterilmiştir $(3,13)$. Aleksitimi duyguların sözel ifade edilmesi ve tanımlanmasında zorluk yaşama, sınırı imgesel güçlere sahip olma ve uyaran bağımlı dış-odakıı bir bilişsel tarza sahip olma olarak tanımlanır (14). Aleksitimik bireylerin MKB dahil olmak üzere birçok psikiyatrik bozukluğa sahip oldukları bildirilmiştir (14).

Dürtü kontrol problemi; genelde istenmeyen sonuçlara yol açan, ortama uygun olmayan veya aşırı riskli, yeterince düşünülmemiş çeşitli davranışları kapsar. Alkol Kullanım Bozukluğu (AKB) ve MKB' de sağıklı kontrollere göre dürtüsellik oranının yüksek olduğu bildirilmiştir (15). Opioid Kullanım Bozukluğu olan hastalarla yapılan bir çalışmada, dürtüsellik düzeyi yüksek olan hastaların intihar girişiminin daha fazla olduğu gösterilmiştir (16). Intihar davranışı gösteren AKB' lerin psikolojik dayanıklılık ile ilişkilendirilen ayrılık, ailesel sorunlar, maddi güçlükler ve işsizlik gibi sorunları daha çok yaşadıkları bildirilmiştir (17).

Bu çalışmada literatürden edinilen bilgiler ışığında, DS kapsamında takipleri ayaktan yapılan MKB tanılı bireylerde psikolojik acı, çocukluk çağı travmaları, aleksitimi, dürtüsellik ve psikolojik dayanıkılığın intihar girişimi ile ilişkili öngördürücüler arasında değerlendirilebileceği varsayılmıştır. Bu kapsamda intihar girişim öyküsü olan MKB tanılı hastalarda psikolojik acı başta olmak üzere çocuk çağı travmaları, dürtüsellik düzeyi, aleksitminin daha yüksek, psikolojik dayanıkılıklarının da daha düşük düzeyde olabileceğini varsayılmıştır. Belirlenen örneklem grubunda intihar davranışını değerlendiren araştırmalar bulunmakla birlikte, intihar davranışıyla ilişkili olabilecek belirlediğimiz olası risk faktörlerinin değerlendirilmesi ve bu özel popülasyonda intihar davranışını değerlendirmede bu risk faktörlerinin etkileri açısından çalışmamızın literatüre katkısı olacağını düşünülmüştür.

\section{Yöntem}

\section{Örneklem}

Çalışmamızın örneklemi Malatya Eğitim ve Araştırma Hastanesi Ruh Sağlığı ve Hastalıkları Bölümünde yer alan DS birimine adli kanallarla yönlendirilen MKB tanılı hastalar ve sağlıklı kontrollerden oluşturulmuştur. Kesitsel tasarım olarak yapılan araştırmaya alınan katılımcılar 3 gruba ayrımıştır. Birinci gruba, son 1 ay içerisinde intihar girişimi öyküsü olan MKB tanılı hastalar; ikinci gruba intihar girişim öyküsü olmayan MKB tanılı hastalar dahil edilmiştir. Üçüncü grup da mevcut hali ile veya geçirilmiş herhangi bir psikiyatrik tanısı 
olmayan, kişisel beyan ile de bilinen herhangi bir kronik fiziksel hastalığı olmadığı bildirilen sağlıkı kontrollerden oluşturulmuştur. Yapılan güç analizinde; $\alpha=0,05,1-\beta$ (güç)=0,80 alındığında; gruplar arasında \%80 güç \%95 güven aralığı referans alınarak yapılan örneklem büyüklüğü analizinde ulașılması gereken minimum örneklem büyüklüğü 120 (Grup 1:40, grup2:40, Grup 3:40 ) olarak hesaplanmıştır.

Araştırmamıza 18-65 yaş aralığında olan, Depresif Bozukluklar (DB), Psikotik Bozukluk, Bipolar Bozukluk, Mental Retardasyon, nörolojik ve kronik fiziksel hastalığı olmayan, en az okuma yazma düzeyinde eğitim almış olan katılımcılar dahil edilmiştir.

\section{İşlem}

01/08/2020-01/11/2020 tarihleri arasında DS Biriminde takipli ve çalışmaya katımayı kabul eden 120 hastadan onam formu alındıktan sonra hastalar iki psikiyatri uzmanı tarafından değerlendirilmiş ve Ruhsal Bozuklukların Tanısal ve Sayımsal El Kitabının 5. baskısına (DSM-5) göre MKB tanısını karşılayan katılımcılar hasta gruplarına dahil edilmiştir. Son 1 ay içerisinde intihar girişim öyküsü olan hasta grubunda (Grup 1) 50, intihar girișim öyküsü olmayan hasta grubunda (Grup 2) 70 hasta çalışmaya dahil edilmiştir. Tüm katılımcılara; Sosyo-Demografik Veri Formu, Çocukluk Çağı Ruhsal Travma Ölçeği (CTQ-28), Toronto Aleksitimi Ölçeği (TAÖ), Psikolojik Acı Ölçeği (PAÖ), Barratt Dürtüsellik Ölçeği, Psikolojik Dayanıkılık Ölçeği uygulanmıştır. Sosyodemografik veri formu psikiyatri uzmanı tarafından uygulanmış, diğer ölçekler katılımcılara psikiyatri uzmanı tarafından açıklandıktan sonra hastaların kendileri tarafından doldurulmuştur. Her bir katılımcı için 30-45 dakika arasında işlem uygulanmıştır. 120 hastadan 16'sı ölçeklerdeki maddeleri eksik işaretlemesi nedeni ile çalışmaya dahil edilmemiştir. Sağlıkı kontrol grubu da (Grup 3) iki psikiyatri uzmanı tarafından değerlendirilerek çalışmaya alınma kriterlerine uyan 70 hastane çalışanından oluşturulmuştur. Sonuç olarak birinci gruba 40 hasta, ikinci gruba 64 hasta, üçüncü gruba da 70 sağıklı kontrol dahil edilerek çalışmanın örneklemi tamamlanmıştır.

Çalışmamız Helsinki Bildirisine uygun olarak yürütülmüş ve değerlendirme öncesi tüm katılımcılardan yazııı onam formu alınmıştır. Çalışmanın etik kurul onayı İnönü Üniversitesi Malatya Klinik Araştırmalar Etik Kurulu'nun 17/06/2020 tarihli oturumunda 2020/102 protokol numarası ile alınmıştır.

\section{Ölçekler}

\section{Sosyo-demografik Veri Formu}

Tarafımızca oluşturulan veri formu, cinsiyet, eğitim düzeyi, medeni durum, çalışma durumu gibi sosyodemografik veriler ve sigara, alkol, toksikoloji taraması ile aktif madde kullanımı, önceden intihar girişimi öyküsü ile ilgili bilgileri içeriyordu.

\section{Psikolojik Acı Ölçeği (PAÖ)}

PAÖ'i Holden ve arkadaşları. tarafından geliştirilmiş, 13 maddeden oluşan özbildirim ölçeğidir (18). Ölçekteki sorulara yanıtlar 5 puanlık likert türünde verilir. Ölçekten alınan yüksek puanlar daha yüksek psikolojik acıyı gösterir. Türkçe geçerlilik ve güvenilirlik çalışması Demirkol ve arkadaşları tarafından 2018 yılında yapıımıştır ve bu çalışmada cronbach alfa değeri 0,98 bulunmuştur (19).

\section{Toronto Aleksitimi Ölçeği (TAÖ)}

Bagby ve arkadaşları tarafından geliştirilen 20 soruluk ölçeğin Türkçe uyarlaması Güleç ve arkadaşları tarafından yapılmıştır $(20,21)$. Ölçek 5'li likert tipinde maddelerden oluşmaktadır $(1=$ Hiçbir zaman, $5=$ Her zaman). Kişiden her bir maddenin kendini ne ölçüde tanımladığını işaretlemesi beklenmektedir. Ölçek aleksitiminin üç alt boyutunu ve ölçekten elde edilecek toplam puanı kapsamaktadır. Bu alt boyutlar; duyguları tanımada güçlük (TAÖ-A), duyguları söze dökmede güçlük (TAÖ-B) ve dışa dönük düşünmedir (TAÖ-C). Ölçeğin geçerlilik çalışmasındaki toplam cronbach alpha değeri 0.78 olarak belirtilmiştir.

\section{Çocukluk Çağı Ruhsal Travmalar ölçeği (CTQ-28)}

Bireylerin geçmişe dönük çocukluk dönemindeki fiziksel istismar, cinsel istismar, duygusal istismar, fiziksel inmal ve duygusal inmal yaşantılarını taramayı hedefleyen 28 maddelik bir öz bildirim ölçeği olarak 
Bernstein ve arkadaşları tarafından geliştirilmiştir (22). Türkçe uyarlama ve geçerlilik-güvenirlilik çalışmasını Şar ve arkadaşları tarafından yapıımışıı (23). Çocukluk çağındaki inmal ve istismarları değerlendirin 5 farklı alt ölçeğe sahiptir. Ölçekte beş farklı yanıt seçeneği bulunur. (1= Hiçbir zaman, $5=$ Çok Sık). Her bir cevap 1 ile 5 arasında puan almaktadır. CTQ-28 puanlarının hesaplanmasında önce olumlu ifadelerden elde edilen puanlar ters çevrilir. Beş alt puanın toplamı CTQ-28 toplam puanını verir. Türkçe geçerlilik ve güvenilirlik çalışmasında cronbach alfa değeri, 0,93 olarak bulunmuştur.

\section{Barratt Dürtüsellik Ölçeği (BDÖ)}

Barratt ve arkadaşları tarafından dürtüselliği ölçmek için geliştirilmiştir (24). Ölçeğinin Türkçe geçerlik ve güvenirlik çalışması Güleç ve arkadaşları tarafından yapıımıştır (25). 30 maddeden oluşan, 1-4 arasında puanlanan, likert tipi bir öz-bildirim ölçeğidir. Bu ölçek ile dürtüsellik hakkında fikir edinildiği gibi alt ölçekleriyle de kişilerin plansızlığı, otokontrol eksikliği ve kendini riske sokacak davranışlarda bulunup bulunmadığı değerlendirilmektedir. Bireyin kendisinden yanıt olarak 'nadiren/hiçbir zaman', 'bazen', 'sıklıkla' ve 'hemen her zaman/her zaman' seçeneklerinden en uygun ifadeyi işaretlemesi istenir. Dikkat dürtüselliği (DD), motor dürtüsellik (MD) ve plan yapmama (PY) alt ölçeklerini içeren 3 alt ölçeği vardır. Toplam puanın yüksekliği kişinin dürtüsellik düzeyinin yüksekliğini göstermektedir. Bu ölçeğin geçerlik güvenirlik çalışmasının cronbach iç güvenirlik katsayısı 0.82 dir.

\section{Yetişkinler için Psikolojik Dayanıkllık Ölçeği (PDÖ)}

Friborg ve arkadaşları tarafından geliştirilmiş olup 'kendilik algısı' ve 'gelecek algısı', 'yapısal stil', sosyal yeterlilik', 'aile uyumu' ve 'sosyal kaynaklar' boyutlarını içermektedir (26). Ölçekte, maddelerin tercih edilmesinde önyargılı değerlendirmelerden kaçınmak için, olumlu ve olumsuz özelliklerin farkı taraflarda olduğu, yanıtlar için ise beş ayrı kutucuğun yer aldığı bir format kullanılmaktadır. Şematik biçimde yapılan değerlendirmede psikolojik dayanıkılığın yüksek veya düşük ölçülmesinde puanlama şekli serbest bırakılmıştır. Toplam 33 maddeden oluşan özbildirim niteliğindeki ölçeğin Türkçe geçerlilik ve güvenilirlik çalışması Basım ve Çetin tarafından yapılmıştır (27). Bu çalışmada chronbach alfa değeri 0,86 olarak bulunmuştur.

\section{Veri Analizi}

Verilerin analizinde SPSS-22 programı kullanılmıştır. Normal dağılım testi olarak Kolmogrow Smirnov testi kullanımıştır. Tanımlayıcı istatistiklerde sayısal değişkenler için ortalama, standart sapma, medyan olarak özetlenirken, nitel değişkenler sayı, yüzde olarak verilmiştir. Normal dağılıma uyan verilerde parametrik uymayan verilerde non-parametrik testler kullanılmıştır. Analizlerde verilerimiz normal dağılım göstermediği için ikili karşılaştırmalarda Mann Whitney $U$ testi, üç grup karşılaştırmalarında Kruskal Wallis testi kullanılmışıı. İkili karşılaştırmalarda post-hoc testi olarak Dunn testi kullanılmıştır. Normal dağılım varsayımı karşılanmadığı için korelasyon analizlerinde Spearman korelasyon testi kullanılmıştır. İntihar girişiminde bulunan hasta grubunda intihar riskini tahmin Binary lojistik regresyon analizi kullanılmıştır. Tüm ölçekler ve alt boyutları dahil edilmiştir, modelin bağımlı değişkeni intihar girişimidir. Modelde forward stepwise yöntemi kullanımıştır. $p<0,05$ değeri anlamlı kabul edilmiştir.

\section{Bulgular}

Katılımcıların sosyodemografik özelliklerine ait tanımlayıcı veriler Tablo 1 de sunulmuştur. Araştırmaya dahil edilen katılımcıların intihar girişim öyküsü olan, intihar girişim öyküsü olmayan hastalar ve kontrol grubu olarak 3 gruba ayrıldığında, uygulanan ölçeklerden aldıkları puanların ortalamalarının karşılaştırıması Tablo 2'de verilmiştir. Uygulanan tüm ölçeklerde alt ölçek puanları da dahil olmak üzere gruplar arasında istatistiksel olarak anlamlı farklılık olduğu tespit edilmisştir. Ortalama puanlar arasındaki farkın hangi gruplar arasındaki farktan kaynaklandığını tespit etmek için Post-hoc analiz (Dunn's testi) uygulanmıştır. Farkılıık oluşturan gruplar Tablo 2 'de 'a ' ve 'b' şeklinde işaretlenerek gösterilmiştir. 
Tablo 1. Katılımcıların sosyodemografik özelliklerine ait tanımlayıcı verileri

\begin{tabular}{|c|c|c|c|c|}
\hline & $\begin{array}{l}\text { Intihar Girişim Öyküsü } \\
(+) n=40\end{array}$ & $\begin{array}{l}\text { İnthar Girişim öyküsü } \\
(-) n=64\end{array}$ & $\begin{array}{l}\text { Kontrol } \\
n=70\end{array}$ \\
\hline \multicolumn{2}{|l|}{ Yas (Ort: $\pm S . S)}$. & $23,5 \pm 4,4$ & $25,7 \pm 5,7$ & $30,4 \pm 8,3$ \\
\hline \multirow[t]{2}{*}{ Cinsiyet } & Erkek & $32(\% 80)$ & $61(\% 95,31)$ & $64(\% 91,42)$ \\
\hline & Kadın & $8(\% 20)$ & $3(\% 4,69)$ & $6(\% 8,58)$ \\
\hline \multirow[t]{3}{*}{ Eğitim } & Illköğretim & $32(\% 80)$ & $31(\% 48,46)$ & $9(\% 12,86)$ \\
\hline & Lise & $8(\% 20)$ & $19(\% 29,68)$ & $23(\% 32,85)$ \\
\hline & Üniversite & 0 & $14(\% 21,86)$ & $38(\% 54,29)$ \\
\hline \multirow[t]{2}{*}{ Medeni durum } & Bekar & $32(\% 80)$ & $44(\% 68,75)$ & $31(\% 44,28)$ \\
\hline & Evli & $8(\% 20)$ & $20(\% 31,25)$ & $39(\% 55,72)$ \\
\hline \multirow[t]{2}{*}{ Meslek } & Çalışmıyor & $28(\% 70)$ & $29(\% 45,32)$ & $14(\% 20)$ \\
\hline & Çalıșiyor & $12(\% 30)$ & $35 \% 54,68)$ & $56(\% 80)$ \\
\hline \multirow[t]{2}{*}{ Sigara } & Var & $36(\% 90)$ & $53(\% 82,81)$ & $21(\% 30)$ \\
\hline & Yok & $4(\% 10)$ & $11(\% 17,29)$ & $49(\% 70)$ \\
\hline \multirow[t]{2}{*}{ Alkol } & Var & $22(\% 55)$ & $14(\% 21,88)$ & 0 \\
\hline & Yok & $18(\% 45)$ & $50(\% 78,12)$ & $70(\% 100)$ \\
\hline Aktif Madde & Var & $18(\% 45)$ & $19(\% 26,69)$ & 0 \\
\hline Kullanımı & Yok & $22(\% 55)$ & $45(\% 70,31)$ & $70(\% 100)$ \\
\hline
\end{tabular}

(Ort: \pm S.S.: Ortalama Standart Sapma)

Tablo 2: Katılımcıların Psikolojik Acı Öıçeği, Toronto Aleksitmi Ölçeği, Psikolojik Dayanıkılıı Ölçeği, Barratt Dürtüsellik Ölçeği, Çocukluk Çağı Ruhsal Travmaları Ölçeği-28' den aldıkları ortalama puanların karşılaştırılması

\begin{tabular}{|c|c|c|c|c|c|c|c|c|c|c|c|}
\hline & & \multicolumn{3}{|c|}{$\begin{array}{l}\text { Intihar girişim öyküsü } \\
\qquad(+)(n=40)\end{array}$} & \multicolumn{3}{|c|}{$\begin{array}{l}\text { Intihar girişim öyküsü } \\
(-)(\mathrm{n}=64)\end{array}$} & \multicolumn{3}{|c|}{$\begin{array}{l}\text { Kontrol } \\
(n=70)\end{array}$} & \multirow[t]{2}{*}{$p$} \\
\hline & & Ort. & S.S & Med. & Ort. & S.S & Med. & Ort. & S.S & Med. & \\
\hline \multicolumn{2}{|l|}{ PAÖ } & $40,0^{a, b}$ & 16,9 & 41,5 & $19,1^{\mathrm{a}}$ & 8,8 & 16,0 & $23,3^{b}$ & 13,0 & 17,0 & $<0.001$ \\
\hline \multirow[t]{4}{*}{ TAÖ } & TAÖ-A & $21,3^{a, b}$ & 4,0 & 21,0 & $13,0^{\mathrm{a}}$ & 6,4 & 11,0 & $13,7^{b}$ & 6,9 & 12,0 & $<0.001$ \\
\hline & TAÖ-B & $16,5^{a, b}$ & 4,3 & 15,5 & $12,3^{\mathrm{a}}$ & 3,4 & 12,0 & $12,0^{\mathrm{b}}$ & 4,4 & 11,5 & $<0.001$ \\
\hline & TAÖ-C & 24,1 & 4,5 & 23,0 & $25,1^{\mathrm{a}}$ & 6,4 & 23,0 & $22,4^{\mathrm{a}}$ & 5,9 & 20,0 & $<0.001$ \\
\hline & TAÖ-T & $62,0^{a, b}$ & 8,7 & 61,5 & $50,6^{b}$ & 11,8 & 49,5 & $48,2^{\mathrm{a}}$ & 11,8 & 48,0 & $<0.001$ \\
\hline \multirow[t]{6}{*}{ PDÖ } & Kendilik Algısı & $20,0^{a, b}$ & 3,6 & 19,0 & $23,7^{\mathrm{a}}$ & 6,3 & 26,0 & $24,2^{b}$ & 4,8 & 24,5 & $<0.001$ \\
\hline & Gelecek Algısı & $11,9^{a, b}$ & 4,1 & 12,0 & $15,9^{a}$ & 4,5 & 16,5 & $15,0^{b}$ & 4,6 & 17,0 & $<0.001$ \\
\hline & Yapısal Stil & $14,2^{a, b}$ & 3,2 & 15,0 & $15,8^{a}$ & 4,1 & 16,0 & $15,9^{b}$ & 4,2 & 17,0 & 0.015 \\
\hline & Sosyal Yeterlilik & $17,1^{\mathrm{a}}$ & 2,7 & 17,0 & 18,2 & 5,3 & 17,5 & $19,4^{\mathrm{a}}$ & 4,1 & 20,0 & 0.007 \\
\hline & Aile Uyumu & $19,0^{\mathrm{a}}$ & 5,5 & 19,0 & $24,6^{a, b}$ & 5,9 & 26,0 & $21,9^{b}$ & 6,5 & 23,0 & $<0.001$ \\
\hline & Sosyal Kaynaklar & $22,4^{a, b}$ & 6,3 & 22,0 & $27,1^{\mathrm{a}}$ & 6,2 & 27,0 & $26,1^{b}$ & 5,8 & 26,0 & $<0.001$ \\
\hline \multirow[t]{4}{*}{ BDÖ } & DD & $17,6^{a, b}$ & 3,2 & 18,0 & $13,7^{\mathrm{a}}$ & 3,8 & 14,0 & $14,4^{b}$ & 4,7 & 13,5 & $<0.001$ \\
\hline & MD & $22,2^{a, b}$ & 5,4 & 19,0 & $17,7^{\mathrm{a}}$ & 4,2 & 17,0 & $19,0^{\mathrm{b}}$ & 4,4 & 18,0 & $<0.001$ \\
\hline & PY & $29,4^{a, b}$ & 4,6 & 28,0 & $24,3^{a}$ & 5,2 & 25,0 & $23,7^{b}$ & 5,1 & 23,0 & $<0.001$ \\
\hline & BDÖ-TOPLAM & $69,3^{a, b}$ & 10,3 & 66,0 & $55,8^{a}$ & 10,3 & 55,5 & $57,2^{b}$ & 13,9 & 57,5 & $<0.001$ \\
\hline \multirow[t]{6}{*}{ CTQ-28 } & Duygusal istismar & $9,7^{a, b}$ & 3,5 & 9,0 & $6,2^{\mathrm{a}}$ & 2,4 & 5,0 & $6,9^{b}$ & 3,0 & 5,0 & $<0.001$ \\
\hline & Fiziksel Istismar & $8,0^{a, b}$ & 2,7 & 8,0 & $5,7^{\mathrm{a}}$ & 2,7 & 5,0 & $6,1^{b}$ & 2,5 & 5,0 & $<0.001$ \\
\hline & Fiziksel İhmal & $11,6^{a, b}$ & 3,7 & 12,5 & $8,8^{a}$ & 3,2 & 9,0 & $7,6^{b}$ & 2,9 & 7,0 & $<0.001$ \\
\hline & Duygusal İhmal & $15,0^{a, b}$ & 4,8 & 15,0 & $11,0^{\mathrm{a}}$ & 4,9 & 10,0 & $11,6^{b}$ & 4,7 & 9,0 & $<0.001$ \\
\hline & Cinsel İstismar & $5,9^{a, b}$ & 1,1 & 5,5 & $5,5^{a}$ & 1,9 & 5,0 & $6,0^{\mathrm{b}}$ & 2,7 & 5,0 & $<0.001$ \\
\hline & Toplam & $50,3^{a, b}$ & 13,6 & 53,0 & $37,4^{a}$ & 12,3 & 35,0 & $38,4^{b}$ & 12,2 & 33,0 & $<0.001$ \\
\hline
\end{tabular}

a ve $b$ fark olan alt grupları simgelemektedir. a veya b sembolü olan hücreler arasında fark vardır.

PAÖ: Psikolojik Acı Ölçeği, TAÖ: Toronto Aleksitimi Ölçeği, TAÖ-A: Duyguları Tanımlamada Güçlük Alt Boyutu, TAÖ-B: Duyguları Söze Dökmede Güçlük Alt Boyutu, TAÖ-C: Dıșa Dönük Düșünme Alt Boyutu TAÖ-T: Toronto Aleksitimi Ölçeği Toplam Puanı; PDÖ: Psikolojik Dayanıkllık Ölcceği; BDÖ: Barratt Dürtüsellik Ölçeği, DD: Dikkat dürtüselliği, MD: Motor dürtüsellik, PY: Plan yapmama, BDÖ-Toplam: Barratt Dürtüsellik Ölçeği Toplam puan,; CTQ-28: Çocukluk Çağı Ruhsal Travmaları Ölçeği (Kruskal Wallis testi)

Intihar girişiminde bulunan hasta grubunda intihar riskini tahmin etmek için kurulan modele göre yapılan lojistik regresyon analizinin sonuçları Tablo 3'te sunulmuştur. Araştırmada kullanılan tüm ölçekler ve alt boyutlarının dahil edilerek intihar girişimi riskini tahmin etmek için kurulan modelde (forward stepwise) PAÖ, TAÖ-A, PDÖ sosyal yeterlilik ve BDÖ-toplam değişkenlerinin modele anlamlı katkı yaptığı bulunmuştur. TAÖ-A ölçeğinden alınan puandaki artışın intihar riskinde 1,162 kat, PAÖ ölçeğinden alınan puandaki artışın 1,082 kat, BDÖ-toplamından alınan puanlardaki artış 1.096, PDÖ-sosyal yeterlilik 
ölçeğinde alınan puanlarda azalma 1.203 kat intihar riskinde artışa neden olmaktadır. Anlamlı olan dört değişkenin intihar riskindeki değişimin \% 65.6'sını açıkladığı bulunmuştur.

Tablo 3: Intihar girişim öyküsü (+) ve (-) olan hasta gruplarında İntihar riski lojistik regresyon analizi

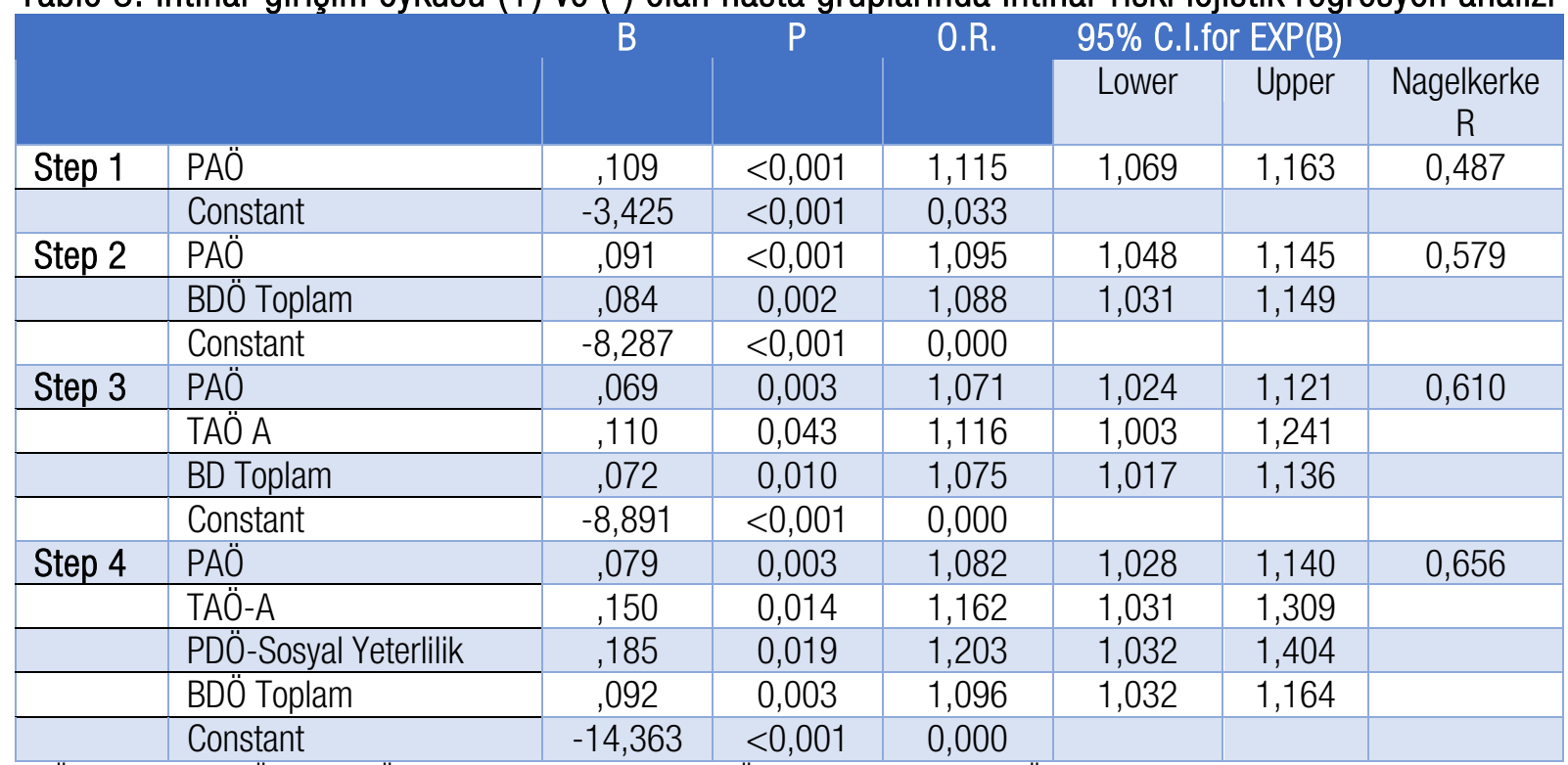

PAÖ: PSikolojik Acı Ölçeği, BDÖ-Toplam: Barratt Dürtüsellik Ölçeği Toplam puan, TAÖ-A: Duyguları Tanımlamada Güçlük Alt Boyutu, PDÖ: Psikolojik Dayanıklılık Ölçeği ( Binary lojistik regresyon testi)

İntihar girişimi öyküsü bulunan hastalarda PAÖ ile diğer ölçekler arasındaki korelasyonlara ait bulgular Tablo 4'de sunulmuştur. PAÖ ile TAÖ-A arasında zayıf, TAÖ-B ve TAÖ-T ile çok yüksek düzeyde aynı yönde korelasyon saptanmıştır. PAÖ ile PDÖ alt ölçeklerinden gelecek algısı, aile uyumu ile ters yönde orta düzeyde korelasyon olduğu tespit edilmiștir. PAÖ ile BDÖ-PY ile aynı yönde zayıf düzeyde korelasyon bulunmuştur. PAÖ ile CTQ-28 alt ölçeklerinden duygusal istismar, fiziksel inmal, cinsel istismar ile orta, duygusal inmal ile çok yüksek, CTQ-28-toplam puanı ile de yüksek düzeyde korelasyon olduğu tespit edilmiştir.

Tablo 4: İntihar girişim öyküsü (+) hasta grubunda Psikolojik Acı Ölçeğinin Toronto Aleksitmi Ölçeği, Psikolojik Dayanıklılık Ölçeği, Barratt Dürtüsellik Ölçeği, Çocukluk Çağı Ruhsal Travmaları Ölçeği ile korelasyonu

\begin{tabular}{|l|c|c|}
\hline TAÖ-A & $\mathrm{r}$ & $\mathrm{P}$ \\
\hline TAÖ-B & 0,354 & 0,025 \\
\hline TAÖ-T & 0,779 & $<0,01$ \\
\hline PDÖ-Gelecek Algısı & 0,776 & $<0,01$ \\
\hline PDÖ-Aile Uyumu & $-0,590$ & $<0,01$ \\
\hline BDÖ-PY & $-0,441$ & 0,004 \\
\hline CTQ-28-Duygusal İstismar & 0,349 & 0,027 \\
\hline CTQ-28-Fiziksel İhmal & 0,404 & 0,010 \\
\hline CTQ-28-Duygusal İhmal & 0,542 & $<0,01$ \\
\hline CTQ-28-Cinsel İstismar & 0,916 & $<0,01$ \\
\hline CTQ-28-Toplam & 0,475 & 0,002 \\
\hline
\end{tabular}

TAÖ: Toronto Aleksitimi Ölçeği, TAÖ-A: Duyguları Tanımlamada Güçlük Alt Boyutu, TAÖ-B: Duyguları Söze Dökmede Güçlük Alt Boyutu, TAÖ-C: Dışa Dönük Düşünme Alt Boyutu TAÖ-T: Toronto Aleksitimi Ölçeği Toplam Puanı; PDÖ: Psikolojik Dayanıklılık ÖIçeği; BDÖ-PY: Barratt Dürtüsellik Ölçeği Plan yapmama Alt Boyutu, BDÖ-Toplam: Barratt Dürtüsellik Ölçeği Toplam puan, CTQ-28: Çocukluk Çağı Ruhsal Travmaları Ölçeği (Spearman korelasyon testi) 


\section{Tartışma}

Çalışmamızın önemli bulgularından birisi intihar girişimi olan MKB tanılı kişilerde, intihar girişimi olmayan gruba ve sağ|ıkı kontrol grubuna göre psikolojik acı düzeyinin yüksek olduğunun saptanmasıdır. Veroochio ve arkadaşları tarafından da belirtildiği gibi psikolojik acı intihar davranışı için önemli bir risk faktörüdür (28). Çalışmalarda özellikle DB tanıı hastalarda psikolojik acı düzeylerinin intihar davranışı ile ilişkili olduğu gösterilmiştir $(29,30)$. Psikolojik acının intihar davranışı için depresyondan bağımsız bir risk etkeni olduğu bildirilmiştir (31). Özel bir popülasyon sayılabilecek MKB tanılı bireylerde de intihar davranışı ile psikolojik acı düzeylerinin ilişkili bulunması literatür ile uyumlu bir bulgudur. MKB tanılı bireylerde de intihar davranışını öngörmede psikolojik acı düzeylerinin önemli olabileceği düşünülebilinir.

Çalışmamızda intihar girişim öyküsü olan hastaların, intihar girişim öyküsü olmayan hastalara ve sağıkı kontrollere göre aleksitimi toplam, duygularını tanıma ve duygularını ifade etme alt kategorilerinden daha yüksek puan aldığı saptanmıştır. Bir kişilik özelliği olarak nitelendirilen aleksitiminin intihar için önemli bir risk faktörü oluşturabileceği bildirilmiştir (32). Bunun yanında intihar riski ve aleksitimi düzeyleri arasında anlamlı ilişki saptamayan yayınlarda vardır (33-35). Bu farklı sonuçların aleksitimi ile intihar davranışı arasındaki ilişkinin incelenmesinde çalışmaların intihar düşüncesi, intihar girişimleri veya kendine zarar verici davranışa odaklanıp odaklanmadığına bağlı olarak değiştiği düşünülmektedir. Bizim örneklemimiz gibi farklı klinik hasta gruplarında aleksitimi ve intihar davranışını değerlendiren araştırmaların yetersiz olduğu bildirilmiştir (32). İntihar girişim öyküsü olan ve olmayan MKB tanılı hastalarda aleksitimi düzeyinin yüksek saptanması duygularını ifade etme, tanımlama ve dışa vurmada güçlük çekiyor olmanın kişi de madde kullanımına yatkınlık yaratabileceğini ön gördürebilir. Çalışmamızda ayrıca intihar davranışı için önemli bir risk faktörü olan psikolojk acı ile aleksitimi arasında güçlü bağlantı saptanmıştır. Türkiye' de şizofreni tanıı hastalar ile yürütülen bir çalışmada da psikolojik acı ile aleksitimi toplam puanı arasında aynı yönde ilişki olduğu gösterilmiştir (36). Literatürde çelişkili bilgiler olsa da çalışmamı, intihar girişim öyküsü olan MKB tanılı bireylerde yüksek aleksitimi düzeyinin belirlenmesinin intihar riskini değerlendirmede önemli olabileceğini düşündürmektedir.

Çalışmamızda intihar girişim öyküsü olan hastalarda diğer gruplara göre dürtüsellik, çocukluk çağı ruhsal travmalarının alt boyutları ve toplam puanının daha yüksek olduğu saptanmıştır. Aynı zamanda psikolojik acı ile plan yapamama dürtüselliği ile aynı yönde zayıf düzeyde; duygusal istismar, fiziksel inmal, cinsel istismar ile aynı yönde orta düzeyde, duygusal inmal ile çok yüksek, CTQ-28 toplam puanı ile de yüksek düzeyde aynı yönde korelasyon olduğu tespit edilmiştir. Çocukluk çağında yaşanan zorlayıcı yaşantıların, davranışsal, duygusal ve bilişsel açıdan psikolojik gelişimi etkilediği bilinmektedir. Çocukluk çağında yaşanan travmalar yetişkinlikte psikiyatrik hastalıkların görülme riskini artırmakta ve tüm tanı kategorilerinde intihar davranışları için risk faktörleri olarak kabul edilmektedir. MKB tanılı hastaların intihar girişim öyküsüne göre karşılaştırıldığı bir çalışmada, çoklu intihar girişim öyküsü olan kişilerde tek intihar girişimi öyküsü olan kişilere göre daha yüksek CTQ-28 puanlarının olduğu ve çocukluk çağı travmasının intihar davranışının başlangıç yaşının ve intihar girişimi sayısının belirleyicisi olabileceği bildirilmiştir (37). Erken yaşta, uzun süreli ve şiddetli travmanın beynin olumsuz eylemlerini baskılama, duyguları kontrol ve düzenleme kapasitesini azaltarak dürtüselliği artırdığı bildirilmiştir (38). Dürtüsellik hem bir travmanın sonucu hem de travmaya karşı geliştirilen patolojik bir tepki olarak düşünülebilir (38). Dürtüselliğin intihar düşüncesinin önemli bir yordayıcısı olduğu ve intihar girişiminde bulunanlarda dürtüsellik ve saldırganlık düzeyinin yüksek olduğu daha önceki çalışmalarda bildirilmiştir $(39,40)$. Literatürde dürtüselliğin intihar girişimlerinden daha çok kendine zarar verici davranışla ilişkili olduğunu bildiren yayınlar da bulunmaktadır (41). Bazı araştırmalarda dürtüsellik ile intihar davranışı arasında hiçbir bağlantı olmadığı ve intiharın dürtüsel bir eylemden ziyade planlı bir davranışın sonucu olduğu ve intihar planı ne kadar ayrıntılı olursa, davranışın 0 kadar ciddi olacağı bildirilmiştir $(42,43)$. Çalışmamızda elde edilen sonuçlar literatürü destekler niteliktedir.

Çalışmamızda intihar girişimi öyküsü olan MKB tanılı kişilerde psikolojik dayanıklıık ölçeği alt ölçeklerinden kendilik algısı, yapısal stil ve sosyal kaynaklar alt ölçeklerinde kontrol grubundan daha düşük puan aldığı, 
sosyal yeterlilik alt ölçeği puanlarının da intihar girişimi olmayan hastalardan daha düşük olduğu saptanmıştır. Ayrıca intihar girişim öyküsü olmayan hastaların aile uyumundan aldığı ortalama puanların kontrol grubundan daha düşük olduğu saptanmıştır. Bu bulguların yanında psikolojik acı ile gelecek algısı ve aile uyumu arasında ters yönde orta düzeyde ilişki saptanmıştır. Son 10-15 yıl içinde çeşitli çalışmalarda psikolojik dayanıkııık ile intihar eğilimi arasındaki ilişki incelemiştir (44). Dayanıklılığın intihar riskine karşı koruyucu bir faktör olduğu düşünülmektedir (46). Intihar için önemli koruyucu faktörlerden birinin arkadaş, aile ve sosyal kurumlar ile bağlantıyı içeren sosyal destek olduğu bildirilmiştir (47). Roy ve arkadaşları. tarafından yapılan bir çalışmada intihar girişiminde bulunan madde bağımlıarında psikolojik dayanıklı̆̆ı̆n, intihar girişimi olmayanlardan daha düşük olduğunu saptanmıştır (48). Başka bir çalışmada, MKB tanılı kişilerde intihar girişiminde bulunan hastaların psikolojik dayanıklılık ölçeğinden aldığı puanların daha düşük olduğu tespit edilmiş ve dayanıklı̆ğın çocukluk travmasıyla ilişkili intihar davranışı riskini azaltan koruyucu bir faktör olabileceği sonucuna varımıştır (48).

Regresyon analizi sonuçlarına göre psikolojik acı, duyguları tanımada güçlük, sosyal yeterlilik ve toplam dürtüselliğin intihar davranışı için önemli yordayıcılar olduğu saptanmıştır. Bu değişkenler arasında en yüksek katkıyı duyguları tanımada güçlüğün yaptığı saptanmıştır. Buna göre intihar davranışı için sosyal yeterlilik düzeylerindeki azalmanın güçlü nedensel belirleyici olacağı buna eşlik eden psikoljik acı, dürtüsellik ve duyguları tanımada güçlük varlığında nedensel belirleyiciliğin daha da yüksek olacağını söylemek uygun olacaktır.

Çalışmanın güçlü yanları arasında örneklem grubunun intiharın yoğun olduğu yaş grubu ile uyumlu olması, bunun yanında ilgili yaş grubun çocukluk çağı travmalarının olası etkilerine daha yakın bir yaş döneminde olması sayılabilir. Intihar davranışı sonrası ilk 1 ay içerisindeki kişilerin çalışmaya alınması da çalışmanın güçlü yanları arasındadır. Çalışmamııın tedavi amacıyla psikiyatri birimine başvurmamış olması da çalışmanın güçlü yanları arasında sayılabilir. Çalışmamızın kısıt|ılıkları arasında sadece intihar girişimini değerlendirmiş olmamız ve intihar davranışı için önemli öncüler olan kendine zarar verme davranışı, intihar düşüncesi ve niyeti gibi kavramların değerlendirilmemiş olması sayllabilir. Bununla birlikte örneklemimizin daha çok erkek bireylerden oluşuyor olması da bir kısıtllık olarak sayılabilir. Ayrıca sadece MKB'li kişileri kullandığı madde ayrımına bakmaksızın çalışmaya dahil etmemizde kullandığı maddenin olası psikolojik etkilerinin değerlendirilmemiş olması açısından bir kısıtlılık olarak sayılabilir.

Sonuç olarak çalışmamı MKB olan bireylerde psikolojik acı, aleksitimi, dürtüsellik ve çocukluk çağı travmalarının yüksek psikolojik dayanıklıı̆ın daha düşük olmasının intihar riskini değerlendirmede öngördürücü etkenler arasında olabileceğini vurgulamaktadır. Özellikle psikolojik acının yüksekliği, duyguları tanımada güçlüğün fazlalığı ve yüksek dürtüsellik düzeyleri ile birlikte sosyal yeterlilik düzeyini düşük olması intihar girişiminde güçlü nedensel etkisinin olduğu tespit edilmiştir. MKB gibi kendine zarar verme riskinin yüksek olduğu popülasyonda intihar riskini öngörmede değerlendirdiğimiz klinik parametrelerin takibinin intihar davranışını engellemede etkili olabileceğini düşünmekteyiz. İlerleyen çalışmalarda kullanılan madde çeşididin, kişilik patolojilerinin, eşlik eden psikiyatrik bozuklukların etkisi araştııımasının uygun olacağını önermekteyiz.

\section{Kaynaklar}

1. World Health Organization. Suicide in the World: Global Health Estimates. Geneva: World Health Organization 2019.

2. Darke S, Ross J, Lynskey M, Teesson M. Attempted suicide among entrants to three treatment modalities for heroin dependence in the Australian Treatment Outcome Study (ATOS): prevalence and risk factors. Drug Alcohol Depend 2004; 73(1): 1-10.

3. Zhornitsky S, Le TM, Dhingra I, et al. Interpersonal risk factors for suicide in cocaine dependence: association with self-esteem, personality traits, and childhood abuse. Suicide Life-Threat Behav 2020; 50(4): 867-883.

4. Maloney E, Degenhardt L, Darke S, et al. Suicidal behaviour and associated risk factors among opioiddependent individuals: a case-control study. Addiction 2007; 102(12): 1933-1941. 


\section{Bağımlılık Dergisi - Journal of Dependence}

5. Practice guideline for the assessment and treatment of patients with suicidal behaviors. Am J Psychiatry 2003; 160(11 Suppl): 1-60.

6. Colak $\mathrm{H}$, Altun U. Denetimli serbestlik kavramının yaptıım teorisi ve penolojik bakımdan tahliil ile pozitif hukukumuzdaki düzenlemeler. Adalet Dergisi 2006; 25: 1-28.

7. Perry AE, Darwin Z, Godfrey C, et al. The effectiveness of interventions for drug-using offenders in the courts, secure astablishments and the community: A sysmatic review. Subst Use Misuse 2009; 44(3): 374-400.

8. Baumeister RF. Suicide as escape from self. Psychol Rev 1990; 97(1): 90-113.

9. Orbach I, Mikulincer M, Sirota P, Schechtman EG. Mental pain: A multidimensional operationalizetion and definition. Suicide Life Threat Behav 2003; 33(3): 219-230.

10. Levinger S, Somer E, Holden RR. The importance of mental pain and physical dissociation in youth suicidality. J Trauma Dissociation 2015; 16(3): 322- 339.

11. Conejero I, Olie E, Calati R, et al. Psychological pain, depression, and suicide: recent evidences and future directions. Curr Psychiatry Rep 2018; 20(5): 33.

12. Bahk YC, Jang SK, Choi KH, Lee SH. The relationship between childhood trauma and suicidal ideation: Role of maltreatment and potential mediators. Psychiatr Invest 2017; 14(1): 37-43.

13. Evren C, Evren B, Dalbudak E, et al. Childhood abuse and neglect as a risk factor for alexithymia in adult male substance dependent inpatients. J Psychoactive Drugs 2009; 41(1): 85-92.

14. Swann AC, Bjork JM, Moeller FG, Dougherty DM. Two models of impulsivity: relationship to personality traits and psychopathology. Biol Psychiatry 2002; 51(12): 988-994.

15. Baykara S, Atmaca M. Erkek opiyat kullanım bozukluğu hastalarında kendine zarar verici davranış ve intihar girişimi öyküsünün dürtüsellik ve bazı klinik verilerle ilişkisi. Anadolu Psikiyatri Derg 2019; 20(1): 29-37.

16. Ögel K. Sigara, Alkol ve Madde Kullanım bozuklukları: Tanı, Tedavi ve Önleme. İstanbul: Yeniden Yayınları, 2010: 325-327.

17. Holden RR, Mehta K, Cunningham EJ, Mcleod LD. Development and preliminary validation of a scale of psychache. Can J Behav Sci 2001; 33(4): 224-232.

18. Demirkol ME, Güleç H, Çakmak S, et al. Psikolojik Acı Ölçeği Türkçe formunun güvenirliliği ve geçerliliği. Anadolu Psikiyatri Derg 2018; 19(Suppl1): 14-20.

19. Bagby RM, Taylor GJ, Parker JDA. The twenty-item Toronto Alexithymia Scale: II. Convergent, discriminant, and concurrent validity. J Psychosom Res 1994; 38: 33-40.

20. Güleç H, Köse S, Güleç MY, et al. Reliability and factorial validity of the Turkish version of the 20- item toronto alexithymia scale (TAS-20). Klin Psikofarmakol Bulteni 2009; 19(3): 214- 220.

21. Bernstein DP, Stein JA, Newcomb MD, et al. Development and validation of a brief screening version of the Childhood Trauma Questionnaire. Child Abuse Negl 2003; 27(2): 169-190.

22. Şar V, Öztürk PE, İkikardeș E. Çocukluk çağı ruhsal travma ölçeğinin Türkçe uyarlamasının geçerlilik ve güvenilirliği. Türkiye Klinikleri Tıp Bilimleri Dergisi 2012; 32(4): 1054-1063.

23. Patton JH, Stanford MS, Barratt ES. Factor structure of the Barratt Impulsiveness Scale. J Clin Psychol 1995; 51(6): 768-774.

24. Güleç H, Tamam L, Güleç MY, et al. Psychometric properties of the Turkish version of the Barratt Impulsiveness Scale-11. Klin Psikofarmakol Bülteni 2008; 18(4): 251-258.

25. Friborg 0 , Barlaug D, Martinussen M, et al. Resilience in Relation to Personality and Intelligence. Int J Methods Psychiatr Res 2005; 14(1): 29-42.

26. Basım H, Çetin F. Yetişkinler için psikolojik dayanıklılık ölçeği'nin güvenilirlik ve geçerlilik çalışması. Türk Psikiyatri Derg 2011; 22(2): 104-114.

27. Verrocchio MC, Carrozzino D, Marchetti D, et al. Mental pain and suicide: a systematic review of the literature. Front Psychiatry 2016; 20(7): 108.

28. Demirkol ME, Uğur K, Tamam L. The mediating effects of psychache and dissociation in the relationship between childhood trauma and suicide attempts. Anadolu Psikiyatri Derg 2020; 21(5): 453-460.

29. Uğur K, Demirkol ME, Tamam L. The mediating roles of psychological pain and dream anxiety in the relationship between sleep disturbance and suicide. Arch Suicide Res 2020; doi: 10.1080/13811118.2020.1740124.

30. Levinger S, Somer E, Holden RR. The importance of mental pain and physical dissociation in youth suicidality. J Trauma Dissociation 2015; 16(3): 322- 339.

31. Iskric A, Ceniti AK, Bergmans $Y$, et al. Alexithymia and self-harm: A review of nonsuicidal self-injury, suicidal ideation, and suicide attempts. Psychiatry Res 2020; 288: 112920.

32. lancu I, Horesh N, Offer D. Alexithymia, affect intensity and emotional range in suicidal patients. Psychother Psychosom 1999; 68(5): 276-280.

33. Sayar K, Acar B, Yazıcı MK. Intihar girişiminde bulunan kişilerde aleksitimi. Nöropsikiyatri Arşivi 1999; 36: 6-11. 
34. Taiminen TJ, Saarijarvi S, Helenius H. Alexithymia in suicide attempters. Acta Psychiatr Scand 1996; 93(3): 195- 198.

35. Demirkol ME, Tamam L, Namli Z, et al. Association of psychache and alexithymia with suicide in patients with schizophrenia. J Nerv Mental Dis 2019; 207(8): 668-674.

36. Roy A. Relationship of childhood trauma to age of first suicide attempt and number of attempts in substance dependent patients. Acta Psychiatr Scand 2004; 109(2): 121-125.

37. Şen M. Psikolojik destek alan ve almayan bireylerde çocukluk çağı travmaları ve dürtüsellik ilişkisinin incelenmesi. Yüksek Lisans Tezi, İstanbul: Maltepe Üniversitesi, Sosyal Bilimler Enstitüsü, 2019.

38. Gvion Y, Horresh N, Levi-Belz Y, et al. Aggression-impulsivity, mental pain, and communication difficulties in medically serious and medically non-serious suicide attempters. Compr Psychiatry 2014; 55(1): 40-50.

39. Bridge JA, Goldstein TR, Brent DA. Adolescent suicide and suicidal behavior. J Child Psychol Psychiatry 2006; 47(3-4): 372-394.

40. McMahon $\mathrm{K}$, Hoertel $\mathrm{N}$, Olfson $\mathrm{M}$, et al. Childhood maltreatment and impulsivity as predictors of interpersonal violence, self-injury and suicide attempts: A national study. Psychiatry Res 2018; 269: 386-393.

41. Price EC. Impulsivity and suicidal ideation or attempt in younger and older adults. Dissertations ThesesGradworks 2012; 53(6): 359-359.

42. Rajalin M, Hirvikoski T, Jokinen J. Family history of suicide and exposure to interpersonal violence in childhood predict suicide in male suicide attempters. J Affect Disord 2013; 148(1): 92-97.

43. Liu DW, Fairweather-Schmidt AK, Roberts RM et al. Does resilience predict suicidality? A lifespan analysis. Arch Suicide Res 2014; 18(4): 453-464.

44. Roy A, Carli V, Sarchiapone M. Resilience mitigates the suicide risk associated with childhood trauma. J Affect Disord 2011; 133(3): 591-594.

45. Youssef NA, Green KT, Beckham JC, Elbogen EB. A 3- year longitudinal study examining the effect of resilience on suicidality in veterans. Ann Clin Psychiatry 2013; 25(1): 59-66.

46. Sher L. Resilience as a focus of suicide research and prevention. Acta Psychiatr Scand 2019; 140(2): 169-180

47. Roy A, Sarchiapone M, Carli V. Low resilience in suicide attempters. Arch Suicide Res 2007; 11(3): 265-269. 